\title{
IN VITRO Cr(VI) SPECIATION IN SYNTHETIC SALIVA AFTER RELEASING FROM ORTHODONTIC BRACKETS USING SILICA-APTES SEPARATION AND GF AAS DETERMINATION
}

\author{
Maciel S. Luz ${ }^{\mathrm{a}, \mathrm{b}}$, Alexandre L. Souza ${ }^{\mathrm{b}}$, Ana C. S. S. Haddad ${ }^{\mathrm{c}}$, André Tartomano ${ }^{\mathrm{c}}$ and Pedro V. Oliveiraa ${ }^{\mathrm{a}, *}$ \\ aDepartamento de Química Fundamental, Instituto de Química, Universidade de São Paulo, 05508-000 São Paulo - SP, Brasil \\ 'Instituto de Pesquisa Tecnológica do Estado de São Paulo, 05508-901 São Paulo - SP, Brasil \\ 'Faculdade de Odontologia, Universidade de São Paulo, 05508-000 São Paulo - SP, Brasil
}

Recebido em 29/12/2015; aceito em 23/05/2016; publicado na web em 20/07/2016

\begin{abstract}
A method for $\mathrm{Cr}(\mathrm{VI})$ speciation in synthetic saliva after releasing from orthodontic brackets, using silica nanoparticles organofunctionalized with (3-aminopropyl)triethoxysilane (APTES) for $\mathrm{Cr}(\mathrm{III}) / \mathrm{Cr}(\mathrm{VI})$ separation and GF AAS determination is proposed. Under the optimized conditions, $\mathrm{Cr}(\mathrm{VI})$ speciation was performed using $150 \mathrm{mg}$ of silica organofunctionalized with $2.0 \%\left(\mathrm{v} \mathrm{v}^{-1}\right)$ of APTES at $\mathrm{pH}$ 8. It was observed different sensitivity when calibrations of GF AAS were performed using $\mathrm{Cr}$ (III) or $\mathrm{Cr}(\mathrm{VI})$ as standard solutions. Consequently, calibrations using stoichiometric mixtures $(\mathrm{Cr}(\mathrm{III})+\mathrm{Cr}(\mathrm{VI}))$ were used for total $\mathrm{Cr}$ determination and calibration using $\mathrm{Cr}(\mathrm{VI})$ was used only for the determination of this specie. The reliability of the proposed silicaAPTES separation procedure and GF AAS determination was checked by addition of both species in synthetic saliva. Recoveries ranging from 97 to $110 \%$ were obtained. The repeatability, based on the relative standard deviation (RSD) inter days was less than $6 \%$. A corrosion test was carried out on 20 orthodontic brackets from two different models, after immersion in synthetic saliva $(\mathrm{pH}=6.0)$ at $37{ }^{\circ} \mathrm{C}$ with agitation $(125 \mathrm{rpm}$ ) for $24 \mathrm{~h}$. It was observed that about $40 \%$ of the total chromium released from the analyzed orthodontic brackets was $\mathrm{Cr}(\mathrm{VI})$.
\end{abstract}

Keywords: speciation, chromium, $\mathrm{Cr}(\mathrm{VI})$, saliva, brackets, GF AAS.

\section{INTRODUCTION}

Recent studies have demonstrated that some brands of orthodontic brackets can release large amounts of $\mathrm{Cr}$, during contact with synthetic saliva. ${ }^{1-4}$ The corrosion of the orthodontic brackets in the oral environment has concerned the clinicians for two main reasons: (i) the possibility of the body absorb the corrosion products suffering localized or systemic effects; or (ii) the clinical performance of the orthodontic appliances. ${ }^{4,5}$ The former is concerned mainly to the toxic effect of $\mathrm{Cr}(\mathrm{VI})$, that can be present in the bracket composition or can be interconvert by $\mathrm{Cr}$ (III) oxidation in the saliva environment. In the oral environment, orthodontic appliances are potentially exposed to physical damage and chemical agents. Factors such as quantity and quality of saliva, salivary $\mathrm{pH}$, board, amount of protein, chemical and physical properties of food and fluid intake and general health oral conditions can influence the orthodontic brackets corrosion in the oral cavity. ${ }^{1,6}$

Most metallic devices used during orthodontic treatment is made of stainless steel type austenitic (AISI type 316L stainless steel), which has $18 \%\left(\mathrm{~m} \mathrm{~m}^{-1}\right)$ chromium, $8 \%\left(\mathrm{~m} \mathrm{~m}^{-1}\right)$ nickel, 2 to $3 \%\left(\mathrm{~m} \mathrm{~m}^{-1}\right)$ molybdenum and low carbon content. ${ }^{4,5}$ The corrosion process of metallic brackets has been linked to the deterioration of their mechanical properties and as mentioned above, to adverse biological effects. ${ }^{6}$

It is well known that the presence of chromium in an alloy can increase its corrosion resistant properties due to the ability to form a protective oxide film over the metallic surface. Consequently, the resistance to the corrosion is an essential criterion for its use as dentistry materials. ${ }^{2}$

Chromium coexists mainly in two oxidation states, $\mathrm{Cr}$ (III) that is essential to the metabolism of glucose, lipids and proteins and $\mathrm{Cr}(\mathrm{VI})$, which is highly toxic due to its allergic, carcinogenic, mutagenic and teratogenic effect for the humans. ${ }^{7-9}$ Thus, the chemical speciation is important to identify species present in a sample and to access the real toxicity of chromium.

The determination of chromium in biological materials may be difficult due to the low concentration of this metal, the great variability of matrix from sample to sample and contamination. Among the instrumental techniques available, graphite furnace atomic absorption spectrometry (GF AAS) is still one of the most widely used for $\mathrm{Cr}$ determination in biological samples. ${ }^{10,11}$ Particularly, AAS is a well-established analytical technique for chromium detection and speciation of $\mathrm{Cr}$ in biological materials using different approaches, such as selective volatilization as $\mathrm{Cr}$ (III)-thenoyltrifluoracetonate, ${ }^{12}$ flow-injection on-line preconcentration on C18 mini-column, based on the selective formation of diethyldithiocarbanate complex of $\mathrm{Cr}(\mathrm{VI})$ in the 1-2 $\mathrm{pH}$ range and $\mathrm{Cr}(\mathrm{III})$ in the $4-9 \mathrm{pH}$ range, ${ }^{13}$ solid-phase extraction using ammonium pyrrolidinedithiocarbamate (APDC)$\mathrm{Cr}$ (III) complex on Diaion HP-2MG resin, ${ }^{14} \mathrm{Cr}$ (III) extraction and preconcentration on silica gel chemically modified with $\mathrm{Nb}_{2} \mathrm{O}_{5}{ }^{15}$ and glass beads surface modified with 3-aminopropyl triethoxysilane (APTES) and glutaraldehyde for $\mathrm{Cr}(\mathrm{III}) / \mathrm{Cr}(\mathrm{VI})$ speciation in seawater. ${ }^{16}$ Among the solid-phase extraction, silica organofunctionalized with APTES ${ }^{17-21}$ and 3-(2-aminoethylamino) propyltrimethoxysilane (AAPTMS $)^{22}$ has been successfully used for separation and preconcentration of chromium species in different samples. The APTES contains the amino group that can act as ligant for ions of transition metals (e.g. Cr) in solution.

Considering that chromium can be released from orthodontic brackets and the toxic effect of $\mathrm{Cr}(\mathrm{VI})$, the aim of this work is to propose an in vitro method for $\mathrm{Cr}(\mathrm{VI})$ speciation in synthetic saliva after releasing from orthodontic brackets, using silica nanoparticles organofunctionalized with (3-aminopropyl)triethoxysilane (APTES) for analyte separation prior to analyte detection using GF AAS. 


\section{EXPERIMENTAL}

\section{Apparatus}

The Cr determination was carried out using a GF AAS spectrometer, model SIMAA- $6000^{\circledR}$, equipped with Echelle grating, solid-state detector, longitudinal Zeeman-effect background correction system and standard THGA $^{\circledR}$ tubes with pyrolytically coated integrated platform (PerkinElmer Life and Analytical Sciences, Shelton, CT, USA). A hollow cathode lamp of chromium $(\lambda=357.0 \mathrm{~nm}$, current lamp $=$ $25 \mathrm{~mA}$, and spectral band pass $=0.7 \mathrm{~nm}$ ) was used throughout in the work. An AS-72 autosampler (PerkinElmer) was used for transferring reference solutions and samples from polypropylene cups to the graphite tube. Argon 99.998\% ( $\mathrm{v} \mathrm{v}^{-1}$ ) (Air Liquid Brazil S/A, São Paulo, Brazil) was used as protective and purge gas. All absorbance signals were based on the integrated peak area.

An orbital shaker and a centrifuge (Quimis Scientific Equipments, São Paulo, Brazil) were used to shake and to separate silica from supernatant solution, respectively.

\section{Reagents and materials}

The glassware, polypropylene flasks (Falcon tubes) and autosampler cups were cleaned as follows: washed with detergent solution, soaked in $10 \%\left(\mathrm{v} \mathrm{v}^{-1}\right) \mathrm{HNO}_{3}$ for $24 \mathrm{~h}$, rinsed with high-purity deionized water, dried and stored in a closed polypropylene container.

High-purity water with final resistivity of $18.2 \mathrm{M} \Omega \mathrm{cm}$ was obtained by a Milli- ${ }^{\circledR}$ water purification system (Millipore, Bedford, MA, USA). Nitric acid 65\% ( $\left.\mathrm{m} \mathrm{m}^{-1}\right)$ (Merck, Darmstadt, Germany), hydrochloric acid 37\% ( $\left.\mathrm{m} \mathrm{m}^{-1}\right)$ (Merck) and sodium hydroxide (Merck) were used for silica pretreatment and $\mathrm{pH}$ adjustment. A high-purity $10 \mathrm{mg} \mathrm{L}^{-1}$ of $\mathrm{Mg}\left(\mathrm{NO}_{3}\right)_{2}$ (Merck) was used as chemical modifier. The calibration solutions were prepared by successive dilution of $1000 \mathrm{mg} \mathrm{L}^{-1}$ of $\mathrm{Cr}(\mathrm{III})\left(\mathrm{CrCl}_{3}\right.$ in $\left.4.2 \% \mathrm{v} \mathrm{v}^{-1} \mathrm{HCl}\right)$ and $\mathrm{Cr}(\mathrm{VI})$ $\left(\mathrm{K}_{2} \mathrm{Cr}_{2} \mathrm{O}_{7}\right.$ in $\left.\mathrm{H}_{2} \mathrm{O}\right)$ Titrisol ${ }^{\circledR}$ from Merck.

Silica nanoparticles $\mathrm{HDK}^{\circledR} \mathrm{T} 40$ (Wacker, Germany) with surface area of about $400 \mathrm{~m}^{2} \mathrm{~g}^{-1}$ and $7 \mathrm{~nm}$ diameter were used throughout this work. The surface area of particle was calculated by means of BET (Brunauer, Emmet and Teller). The reagent (3-aminopropyl) triethoxysilane (APTES) 98\% ( $\left.\mathrm{v} \mathrm{v}^{-1}\right)$ (Sigma-Aldrich) was used for the silica nanoparticles organofuctionalization.

Three different solutions were used to prepare the synthetic saliva, with the following reagents/concentrations $\left(\mathrm{mol} \mathrm{L}^{-1}\right)$ : (Solution A) $\mathrm{NaH}_{2} \mathrm{PO}_{4} / 0.233+\mathrm{KCl} / 1.164+\mathrm{NaCl} / 0.123+\mathrm{NH}_{4} \mathrm{Cl} / 0.205+$ sodium citrate/3.74 $\times 10^{-3}+$ lactic acid/0.039; (Solution B) urea/0.167 + uric acid/4.46×10-3 $+\mathrm{NaOH} / 5 \times 10^{-3}$; (Solution C) KSCN/0.123. ${ }^{23}$ The saliva solution was prepared daily by mixing the solutions $\mathrm{A}, \mathrm{B}$ and $\mathrm{C}(1: 1: 1)$ and then diluted 50 times with high-purity deionized water. The $\mathrm{pH}$ of the synthetic saliva solution was adjusted with $\mathrm{HCl}$ up to the physiological values ( $\mathrm{pH}$ 6).

Based on previous results, about the amounts of $\mathrm{Cr}$ released from commercially available brackets, ${ }^{20}$ samples of two different models of stainless steel orthodontic brackets (MBT ${ }^{\mathrm{TM}}$ ), that presented high corrosion level, were used to perform the $\mathrm{Cr}(\mathrm{VI})$ speciation.

\section{General procedure}

The silica nanoparticles organofunctionalization and characterization were done as previously reported in the literature. ${ }^{20}$ About $50 \mathrm{~g}$ of silica was washed with $200 \mathrm{~mL}$ of $0.2 \mathrm{~mol} \mathrm{~L}^{-1} \mathrm{HCl}+0.044$ mol L-1 $\mathrm{HNO}_{3}$ under agitation for $24 \mathrm{~h}$, washed several times with high-purity deionized water and dried at $70{ }^{\circ} \mathrm{C}$ for $12 \mathrm{~h}$. About $1 \mathrm{~g}$ of washed silica was organofunctionalized with $0.2,2.0$ and $10 \%(\mathrm{v}$
$\mathrm{V}^{-1}$ ) APTES. The best conditions for $\mathrm{Cr}(\mathrm{VI})$ speciation was $150 \mathrm{mg}$ of silica nanoparticles organofunctionalized with $2.0 \%\left(\mathrm{v} \mathrm{v}^{-1}\right)$ APTES.

The $\mathrm{pH}$ was measured using $150 \mathrm{mg}$ of silica nanoparticles organofunctionalized with $2.0 \%\left(\mathrm{v} \mathrm{v}^{-1}\right)$ APTES suspended in $2.5 \mathrm{~mL}$ of $20 \mu \mathrm{g} \mathrm{L}^{-1} \mathrm{Cr}(\mathrm{III})$ or $20 \mu \mathrm{g} \mathrm{L}^{-1} \mathrm{Cr}(\mathrm{VI})$ in synthetic saliva.

The kinetic of adsorption of the $\mathrm{Cr}(\mathrm{III})$ and $\mathrm{Cr}(\mathrm{VI})$ species on organofunctionalized silica nanoparticles showed to be quite fast, although the amount of $\mathrm{Cr}$ (III) and $\mathrm{Cr}(\mathrm{VI})$ adsorbed were significantly different. For this reason, the time of stirring was not evaluated. About one minute was established for the adsorption. After $\mathrm{pH}$ adjustment with hydrochloric acid or sodium hydroxide, each suspension was centrifuged at $3000 \mathrm{rpm}$ for 5 minutes and the supernatant was analyzed by GF AAS for chromium determination.

Solutions containing $20 \mu \mathrm{g} \mathrm{L}{ }^{-1} \mathrm{Cr}(\mathrm{III})$ or $20 \mu \mathrm{g} \mathrm{L}^{-1} \mathrm{Cr}(\mathrm{VI})$ in water and synthetic saliva were used to optimize the heating program of the GF AAS. A volume of $10 \mu \mathrm{L}$ reference solutions was used to obtain the pyrolysis and atomization temperatures without and with $10 \mu \mathrm{g}$ of $\mathrm{Mg}\left(\mathrm{NO}_{3}\right)_{2}$ as chemical modifier.

Samples of 20 stainless steel orthodontic brackets from two different models were immersed in $5 \mathrm{~mL}$ of synthesized saliva ( $\mathrm{pH}$ (6), at $37^{\circ} \mathrm{C}$, stirred in an orbital shaker at $125 \mathrm{rpm}$ for $24 \mathrm{~h}$, simulating the oral environment. Subsequently, the brackets were separated and an aliquot of $1.0 \mathrm{~mL}$ of the resulting solutions was used for total $\mathrm{Cr}$ determination by GF AAS. Another aliquot of $2.5 \mathrm{~mL}$ was added to $150 \mathrm{mg}$ of organofunctionalized silica modified with $2.0 \% \mathrm{v} \mathrm{v}^{-1}$ of APTES at $\mathrm{pH} 8$, adjusted with $\mathrm{NaOH}$. The suspension was manually shaken for $1 \mathrm{~min}$, centrifuged at $3000 \mathrm{rpm}$ for $5 \mathrm{~min}$ and the supernatant analyzed by GF AAS.

For GF AAS calibration, solutions containing equal mixtures of 1.0 to $10 \mu \mathrm{g} \mathrm{L}^{-1}$ of $\mathrm{Cr}(\mathrm{III})$ and 1.0 to $10 \mu \mathrm{g} \mathrm{L}^{-1}$ of $\mathrm{Cr}(\mathrm{VI})$, total $\mathrm{Cr}$ concentration of 2.0 to $20 \mu \mathrm{g} \mathrm{L}^{-1}$; and solutions containing 2.0 to 20

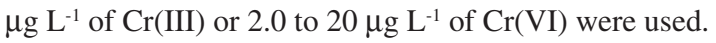

To check the $\mathrm{Cr}(\mathrm{III}) / \mathrm{Cr}(\mathrm{VI})$ interconversion and the reliability of the proposed procedure, two synthetic saliva aliquots were prepared with addition of $3 \mu \mathrm{g} \mathrm{L}^{-1} \mathrm{Cr}(\mathrm{III})+7 \mu \mathrm{g} \mathrm{L}{ }^{-1} \mathrm{Cr}(\mathrm{VI})$ or $7 \mu \mathrm{g} \mathrm{L}^{-1}$ $\mathrm{Cr}(\mathrm{III})+3 \mu \mathrm{g} \mathrm{L^{-1 }} \mathrm{Cr}(\mathrm{VI})$ and keeping the solution for 1 hour at 37 ${ }^{\circ} \mathrm{C}$. Subsequently, these solutions were submitted to the speciation procedure.

\section{RESULTS AND DISCUSSION}

\section{Effect of pH}

The effect of synthesized saliva $\mathrm{pH}$ on the adsorption of $\mathrm{Cr}$ (III) and $\mathrm{Cr}(\mathrm{VI})$ on silica-APTES is shown in Figure 1.

The behavior of $\mathrm{Cr}(\mathrm{VI})$ in the synthetic saliva was very close to that observed for $\mathrm{Cr}(\mathrm{VI})$ in water, while that of $\mathrm{Cr}(\mathrm{III})$ was completely different. ${ }^{20}$ At $\mathrm{pH} 2$, the adsorption was about $60 \%$ of $\mathrm{Cr}(\mathrm{VI})$ and $70 \%$ of $\mathrm{Cr}(\mathrm{III})$ species (see Figure 1). In this $\mathrm{pH}$, the protonation of $-\mathrm{CH}_{2} \mathrm{NH}_{2}$ group of the APTES can occur to form $-\mathrm{CH}_{2} \mathrm{NH}_{3}{ }^{+}$and, consequently, the electrostatic attraction of $\mathrm{Cr}(\mathrm{VI})$ and repulsion of $\mathrm{Cr}$ (III) on the silica-APTES surface is possible. ${ }^{16,20}$ Opposite behaviors were observed for $\mathrm{Cr}$ (III) and $\mathrm{Cr}$ (VI) specie (Figure 1). Previous results for aqueous solutions, at $\mathrm{pH} 2$, revealed almost none adsorption of $\mathrm{Cr}(\mathrm{III})$ on the silica-APTES. ${ }^{20}$ Based on this results, it is possible to suppose some interaction between $\mathrm{Cr}$ (III) and the components of synthetic saliva to form anionic species, allowing the interaction with silica-ATPES.

The increase of the $\mathrm{pH}$ solution decreases the protonation of amino group and increases the electrostatic repulsion of $\mathrm{Cr}(\mathrm{VI})$ specie, as observed in Figure 1. Additionally, the interaction of $\mathrm{Cr}$ (III) with the $-\mathrm{CH}_{2} \mathrm{NH}_{2}$ group takes place, increasing the adsorption of this specie on the silica-APTES. At pH 8, the adsorption of $\mathrm{Cr}$ (III) over 


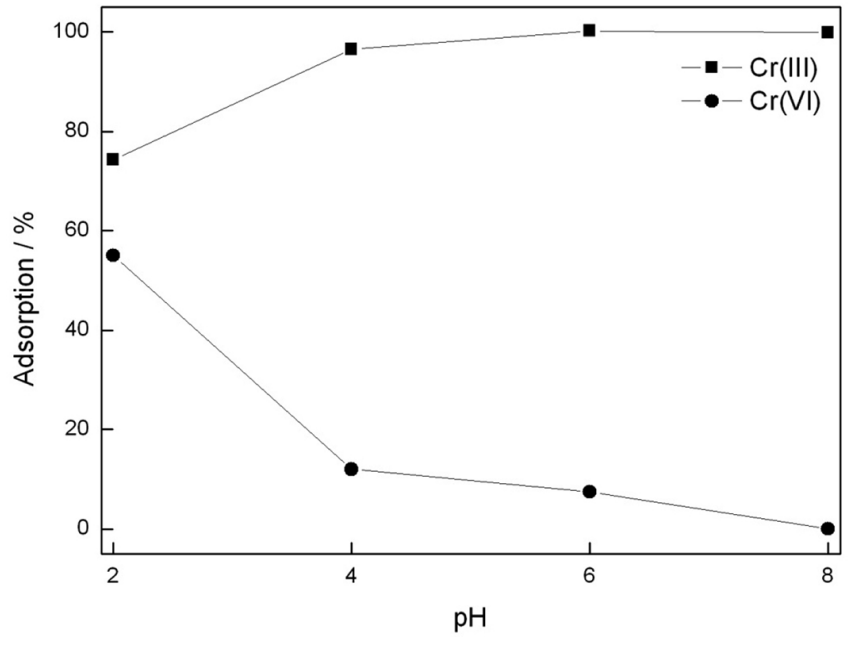

Figure 1. Effect of the synthetic saliva $\mathrm{pH}$ on the adsorption of $\mathrm{Cr}$ species (20 $\mathrm{g} \mathrm{L} \mathrm{L}^{-1}$ each) on the organofunctionalized silica-APTES

the silica-APTES was almost $100 \%$ while $\mathrm{Cr}(\mathrm{VI})$ was negligible.

At $\mathrm{pH} 8$ it was possible to adsorb $\mathrm{Cr}(\mathrm{III})$ on the silica-APTES and determine $\mathrm{Cr}(\mathrm{VI})$ in the solution by GF AAS. The concentration of $\mathrm{Cr}(\mathrm{III})$ can also be calculated by the difference between $\mathrm{Cr}_{\text {Total }}$ and $\mathrm{Cr}(\mathrm{VI})$ concentrations.

The reusability of the silica-APTES was evaluated, whereas $1.0 \mathrm{~mol} \mathrm{~L}^{-1}$ of $\mathrm{HCl}$ was used to desorb $\mathrm{Cr}$ (III). Despite the efficient desorption of $\mathrm{Cr}(\mathrm{III})$, the subsequent procedure of conditioning silica-APTES was not so effective. Considering the small mass of silica-APTES used and the facility to modify a large mass of material, it was decided to not reuse the organic functionalized particles.

\section{Heating program optimization for $\mathrm{Cr}(\mathrm{VI})$ speciation}

The GF AAS heating program was evaluated using $20 \mu \mathrm{g} \mathrm{L}^{-1}$ $\mathrm{Cr}$ (III) and $20 \mu \mathrm{g} \mathrm{L}^{-1} \mathrm{Cr}(\mathrm{VI})$ in synthetic saliva. The best results were observed at $1400{ }^{\circ} \mathrm{C}$ for pyrolysis and $2400{ }^{\circ} \mathrm{C}$ for atomization.

During the optimization of the heating program different sensitivity was observed for $\mathrm{Cr}$ (III) and $\mathrm{Cr}$ (VI) for the same concentration of each species. The absorbance of $\mathrm{Cr}$ (III) in both media studied (water and synthetic saliva solution) was always lower than $\mathrm{Cr}(\mathrm{VI})$. The same results were obtained for $\mathrm{Cr}(\mathrm{III})$ and $\mathrm{Cr}(\mathrm{VI})$ in synthetic saliva, $\mathrm{Cr}(\mathrm{III})$ in $\mathrm{HCl}$ solution or $\mathrm{Cr}(\mathrm{VI})$ in water.

To investigate the reason of the different sensitivities of $\mathrm{Cr}(\mathrm{III})$ and $\mathrm{Cr}(\mathrm{VI})$, calibration curves of $\mathrm{Cr}$ (III) $\left(2.0\right.$ to $\left.20 \mu \mathrm{g} \mathrm{L}^{-1}\right)$ or $\mathrm{Cr}(\mathrm{VI})$ (2.0 to $20 \mu \mathrm{g} \mathrm{L}^{-1}$ ) were obtained, for calibration solutions prepared in water or synthetic saliva, in the absence or presence of $10 \mu \mathrm{g}$ $\mathrm{Mg}\left(\mathrm{NO}_{3}\right)_{2}$, used as chemical modifier in the graphite tube. The results are depicted in Figure 2.

In water medium and without chemical modifier (Figure 2A) the sensitivity of $\mathrm{Cr}(\mathrm{VI})$ (slope $=0.008580 \mathrm{~L} \mathrm{\mu g}^{-1} \mathrm{~s}^{-1}$ ) was twice of that observed for $\mathrm{Cr}$ (III) (slope $=0.004201 \mathrm{~L} \mathrm{\mu g}^{-1} \mathrm{~s}^{-1}$ ). When 10 $\mu \mathrm{g} \mathrm{Mg}\left(\mathrm{NO}_{3}\right)_{2}$ was used as chemical modifier the sensitivity was almost the same for $\mathrm{Cr}(\mathrm{VI})$ (slope $=0.006836 \mathrm{~L} \mathrm{\mu g}^{-1} \mathrm{~s}^{-1}$ ) and $\mathrm{Cr}(\mathrm{III})$

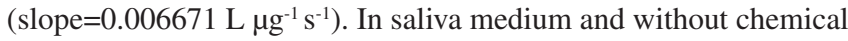
modifier (Figure 2B) the sensitivity for $\mathrm{Cr}(\mathrm{VI})$ (slope $=0.007885 \mathrm{~L}$ $\mu \mathrm{g}^{-1} \mathrm{~s}^{-1}$ ) and $\mathrm{Cr}$ (III) (slope $=0.006529 \mathrm{~L} \mathrm{\mu g}^{-1} \mathrm{~s}^{-1}$ ) was also different, but the difference was lower than that observed for water medium. When the chemical modifier was used the sensitivity for both species in saliva medium was drastically reduced and the difference between

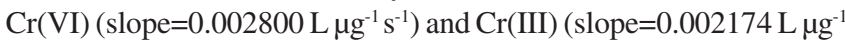
$\left.\mathrm{s}^{-1}\right)$ still persisted. In this case, the total chromium determination in synthetic saliva using only one of the chromium species to prepare the calibration curve is not recommended. So, to avoid systematic errors the use of calibration solutions resulting from the mixture of $\mathrm{Cr}(\mathrm{III})$ and $\mathrm{Cr}(\mathrm{VI})$ species revealed to be more adequate.
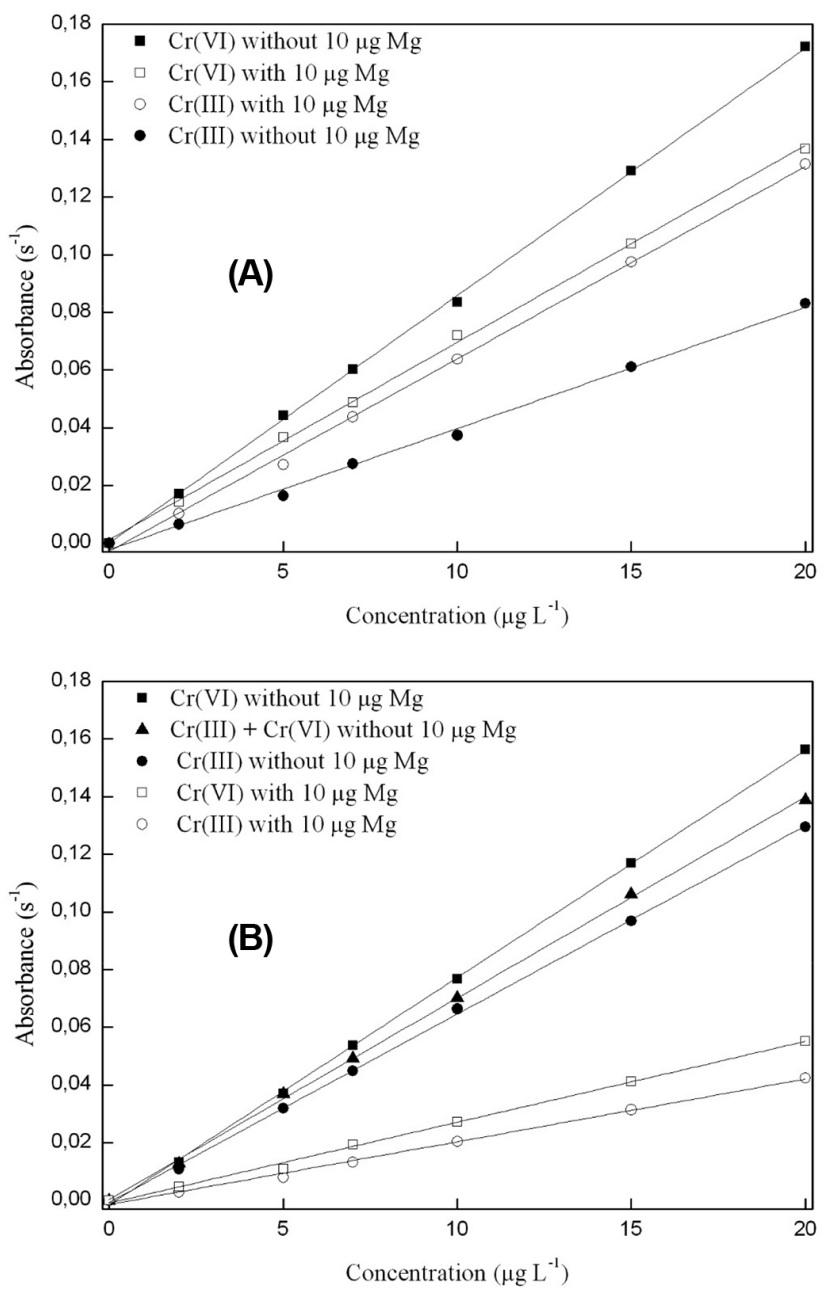

Figure 2. Analytical curves for $\mathrm{Cr}(\mathrm{III})$ and $\mathrm{Cr}(\mathrm{VI})$ in water (A) and synthetic saliva $(B)$ with and without $10 \mu \mathrm{g}$ of $\mathrm{Mg}\left(\mathrm{NO}_{3}\right)_{2}$ as chemical modifier

The explanation for the obtained results can be related to the different interaction of $\mathrm{Cr}(\mathrm{III})$ and $\mathrm{Cr}(\mathrm{VI})$ with the graphite surface, resulting in different atomization mechanism. Thermal decomposition of the carbide ${ }^{24}$ or vaporization of the free metal ${ }^{25}$ has been proposed as atomization mechanisms for chromium in GF AAS. However, these proposed mechanisms do not explain the behavior observed in the present work. It could be supposed that $\mathrm{Cr}$ (III) sensitivity for water medium is strongly affected due to the more effective formation of chromium carbide that is retained on the graphite tube. On the other hand, in presence of synthetic saliva this interaction is reduced due to the formation of $\mathrm{Cr}$ (III) complex with synthetic saliva components and, consequently, the carbide formation is less favored.

In order to verify the influence of saliva components on the chromium species sensitivity, calibration curves of $\mathrm{Cr}$ (III) or $\mathrm{Cr}(\mathrm{VI})$ were prepared in each solution (A, B and C) used to prepare the synthetic saliva. The sensitivity for $\mathrm{Cr}(\mathrm{VI})$ in all solutions was similar, maybe due to the low complexing capability of this species. The presence of oxygen in the $\mathrm{Cr}(\mathrm{VI})$ species $\left(\mathrm{CrO}_{4}{ }^{2-}\right.$ or $\left.\mathrm{Cr}_{2} \mathrm{O}_{7}{ }^{2-}\right)$ can reduce the chromium interaction with graphite, reducing carbide formation and, consequently, increasing the sensitivity. In this way, vaporization of chromium oxide would be one probable atomization route. With 
respect to $\mathrm{Cr}(\mathrm{III})$, the sensitivity was higher for solution $\mathrm{A}$, which contained complexing agents, such as $\mathrm{PO}_{4}^{-3},\left(\mathrm{C}_{3} \mathrm{H}_{5} \mathrm{O}(\mathrm{COO})_{3}\right)^{3-}$ (citrate) and $\mathrm{C}_{3} \mathrm{H}_{5} \mathrm{O}_{3}{ }^{-}$(lactate) that decrease the interaction of $\mathrm{Cr}(\mathrm{III})$ with the graphite tube.

Considering all results, it is possible to conclude that calibration curves with only one of the chromium species (III or VI) in synthetic saliva medium is not recommended for total chromium determination. In this way, stoichiometric mixtures of $\mathrm{Cr}(\mathrm{III})$ and $\mathrm{Cr}(\mathrm{VI})$ were tested to obtain the calibration curve. Indeed, this is not the best way for GF AAS calibration, but this strategy decreases systematic errors associated to the $\mathrm{Cr}(\mathrm{III})$ and $\mathrm{Cr}(\mathrm{VI})$ determination (Figure 2B). It is important to emphasize that this is the first time that the different behavior on the atomization of $\mathrm{Cr}(\mathrm{III})$ and $\mathrm{Cr}(\mathrm{VI})$ was observed and reported in the literature for GF AAS.

An additional study was conducted in order to investigate the necessity to apply the separation procedure for the calibration solutions. Using the silica-APTES separation procedure for each stoichiometric calibration solution of $\mathrm{Cr}$ (III) $+\mathrm{Cr}(\mathrm{VI})$ (2.0 to 20

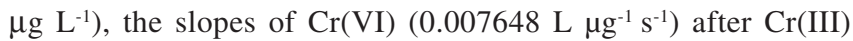
separation was very close to that obtained for $\mathrm{Cr}(\mathrm{VI})$ in solution prepared without addition of $\mathrm{Cr}$ (III) $\left(0.007885 \mathrm{~L} \mathrm{\mu g}^{-1} \mathrm{~s}^{-1}\right)$. This study demonstrated that the determination of $\mathrm{Cr}(\mathrm{VI})$ remaining in the synthetic saliva after $\mathrm{Cr}$ (III) separation can be performed without previous separation of $\mathrm{Cr}(\mathrm{III})$.

The heating program adopted for chromium determination without chemical modifier is depicted in Table 1.

Table 1. Heating program for $\mathrm{Cr}$ determination by GF AAS

\begin{tabular}{lccccc}
\hline Step & Temp. $\left({ }^{\circ} \mathrm{C}\right)$ & Ramp (s) & Hold (s) & $\begin{array}{c}\text { Ar flow } \\
\left(\mathrm{mL} \mathrm{min}^{-1}\right)\end{array}$ & Read \\
\hline Drying I & 110 & 10 & 25 & 250 & No \\
Drying II & 130 & 5 & 15 & 250 & No \\
Pyrolysis & 1400 & 10 & 20 & 250 & No \\
Atomization & 2400 & 0 & 5 & 0 & Yes \\
Cleaning & 2600 & 1 & 3 & 250 & No
\end{tabular}

Injection temperature: $30^{\circ} \mathrm{C}$; Pipette speed: $100 \%$.

\section{Figures of merit}

The calibration curves for total chromium determination and $\mathrm{Cr}(\mathrm{VI})$ speciation in synthetic saliva after the corrosion assay were prepared using stoichiometric mixtures of $\mathrm{Cr}$ (III) $+\mathrm{Cr}$ (VI) (2.0 to 20 $\left.\mu \mathrm{g} \mathrm{L}^{-1}\right)$ and $\mathrm{Cr}(\mathrm{VI})$ (2.0 to $\left.20 \mu \mathrm{g} \mathrm{L}^{-1}\right)$, at $\mathrm{pH} 8.0$, respectively.

The limit of detection (LOD) for total Cr determination was calculated considering the variability of 10 consecutive measurements of synthesized saliva solution (blank), according to $3 s_{\mathrm{blk}} / b\left(s_{\mathrm{blk}}=\right.$ standard deviation of the blank and $b=$ calibration curve slope). To estimate the LOD of $\mathrm{Cr}(\mathrm{VI}), 2.5 \mathrm{~mL}$ of synthesized saliva was shaken manually with $150 \mathrm{mg}$ of silica organofunctionalized with $2.0 \%$ (v $\mathrm{V}^{-1}$ ) APTES, centrifuged at $3000 \mathrm{rpm}$ for $5 \mathrm{~min}$ and the supernatant measured $(n=10)$ by GF AAS. Considering the adopted conditions, the LOD for total $\mathrm{Cr}$ and $\mathrm{Cr}(\mathrm{VI})$ determination was $0.1 \mu \mathrm{g} \mathrm{L}^{-1}$.

The reliability of the proposed silica-APTES separation procedure was checked by addition and recovery of $\mathrm{Cr}$ (III) and $\mathrm{Cr}(\mathrm{VI})$ species in synthetic saliva and the results are presented in Table 2. For both additions, the recoveries were 97 and $110 \%$. The repeatability of method was calculated based on all steps of the method, such as silica modification, separation and determination by GF AAS. The relative standard deviation (RSD) for inter days measurements was less than $6 \%$.
Table 2. The $\mathrm{Cr}(\mathrm{III})$ and $\mathrm{Cr}(\mathrm{VI})$ interconversion study and species recovery

\begin{tabular}{lcccccc}
\hline Species & \multicolumn{2}{c}{ Addition } & \multicolumn{2}{c}{ Determination } & \multicolumn{2}{c}{ Recovery } \\
\cline { 2 - 7 } & $\begin{array}{c}\mathrm{Cr}(\mathrm{III}) \\
\left(\mu \mathrm{g} \mathrm{L}^{-1}\right)\end{array}$ & $\begin{array}{c}\mathrm{Cr}(\mathrm{VI}) \\
\left(\mu \mathrm{g} \mathrm{L}^{-1}\right)\end{array}$ & $\begin{array}{c}\mathrm{Cr}(\mathrm{III}) \\
\left(\mu \mathrm{g} \mathrm{L}^{-1}\right)\end{array}$ & $\begin{array}{c}\mathrm{Cr}(\mathrm{VI}) \\
\left(\mu \mathrm{g} \mathrm{L}^{-1}\right)\end{array}$ & $\begin{array}{c}\mathrm{Cr}_{\text {Total }} \\
\left(\mu \mathrm{g} \mathrm{L}^{-1}\right)\end{array}$ & $\begin{array}{c}\mathrm{Cr}(\mathrm{VI}) \\
(\%)\end{array}$ \\
\hline Mixture 1 & 3 & 7 & $3.2^{* *}$ & $6.8 \pm 0.2^{*}$ & $10.0 \pm 0.1$ & 97 \\
Mixture 2 & 7 & 3 & $6.4^{* *}$ & $3.3 \pm 0.2^{*}$ & $9.7 \pm 0.2$ & 110 \\
\hline
\end{tabular}

* After separation using the proposed method (silica-APTES). ** Calculated by difference between $\mathrm{Cr}_{\text {Total }}$ and $\mathrm{Cr}(\mathrm{VI})$ determined.

\section{Speciation of $\mathrm{Cr}(\mathrm{VI})$ released from brackets}

The results for the 20 brackets corrosion assay analysis are given in Table 3. For both assays, it was detected the presence of $\mathrm{Cr}(\mathrm{VI})$ in the solution (about 39\% of total Cr released). The high release of $\mathrm{Cr}$ from the brackets can be related to the poor quality of the metal alloys used for manufacturing and, consequently, the corrosion process of metallic brackets takes place.

Additional experiments were conducted to get information about $\mathrm{Cr}(\mathrm{VI})$ origin in saliva: (a) by interconversion in the saliva solution, or (b) directly released from the orthodontic brackets.

Table 3. Total $\mathrm{Cr}$ and $\mathrm{Cr}(\mathrm{VI})$ found in synthetic saliva after brackets corrosion assay and $\mathrm{Cr}(\mathrm{III})$ species separation on silica-APTES

\begin{tabular}{lccc}
\hline Bracket Sample $^{*}$ & $\begin{array}{c}\mathrm{Cr}_{\text {Total }} \\
\left(\mu \mathrm{g} \mathrm{L}^{-1}\right)\end{array}$ & $\begin{array}{c}\mathrm{Cr}(\mathrm{VI}) \\
(\mu \mathrm{g} \mathrm{L})^{-1}\end{array}$ & $\begin{array}{c}\mathrm{Cr}(\mathrm{III})^{* *} \\
\left(\mu \mathrm{g} \mathrm{L}^{-1}\right)\end{array}$ \\
\hline 1 & $14.1 \pm 0.3$ & $5.6 \pm 0.9$ & 8.5 \\
2 & $20.3 \pm 0.7$ & $7.2 \pm 0.3$ & 13 \\
\hline $\begin{array}{l}* \mathrm{n}=20 \text { brackets. **Calculated by difference between } \mathrm{Cr}_{\text {Total }} \text { and } \mathrm{Cr}(\mathrm{VI}) \\
\text { determined. }\end{array}$
\end{tabular}

To know if the $\mathrm{Cr}(\mathrm{VI})$ present in synthesized saliva was released from brackets or originated from $\mathrm{Cr}$ (III) oxidation, more experiments were conducted. For this, about $40 \mathrm{mg}$ of metallic chromium powder was submitted to the same procedure used in the brackets corrosion assay and separation using silica-APTES. The analysis of the supernatant revealed $108.0 \pm 0.6 \mu \mathrm{g} \mathrm{L}^{-1}$ of total $\mathrm{Cr}$ and according to the proposed method, $100 \%$ of released chromium was $\mathrm{Cr}$ (III), demonstrating that the saliva medium is not able to convert metallic $\mathrm{Cr}$ in $\mathrm{Cr}(\mathrm{VI})$. Additionally, results of the addition and recovery test (Table 2) demonstrate that there is not interconversion of $\mathrm{Cr}$ (III) to $\mathrm{Cr}(\mathrm{VI})$ or vice-versa in the synthesized saliva environment. Therefore, the $\mathrm{Cr}(\mathrm{VI})$ concentration in saliva after contact with orthodontic brackets is due to the direct release of $\mathrm{Cr}(\mathrm{VI})$ from the material.

In order to investigate the influence of a typical enzyme (mucin) found in the natural saliva on the $\mathrm{Cr}(\mathrm{VI})$ speciation, a mixture of $5 \mu \mathrm{g}$ $\mathrm{L}^{-1}$ of $\mathrm{Cr}(\mathrm{III})$ and $5 \mu \mathrm{g} \mathrm{L}^{-1}$ of $\mathrm{Cr}(\mathrm{VI})$ was prepared with and without $0.1 \%\left(\mathrm{~m} \mathrm{v}^{-1}\right)$ of mucin. The $\mathrm{Cr}(\mathrm{VI})$ concentration found was $5.2 \pm 0.1$ $\mu \mathrm{g} \mathrm{L}^{-1}$ and $5.3 \pm 0.1 \mu \mathrm{g} \mathrm{L}^{-1}$ in the presence and absence of mucin, respectively. Using Student's $t$-test, it was not observed statistic difference of the results for $\mathrm{Cr}(\mathrm{VI})$ in presence and absence of mucin, at $95 \%$ confidence level.

\section{CONCLUSIONS}

Silica nanoparticle organofunctionalized with APTES was very efficient for $\mathrm{Cr}(\mathrm{III}) / \mathrm{Cr}$ (VI) separation, allowing the $\mathrm{Cr}(\mathrm{VI})$ speciation analysis in synthetic saliva after releasing from orthodontic brackets. The proposed method is selective, leading to precise results. The different sensitivity observed for $\mathrm{Cr}(\mathrm{III})$ and $\mathrm{Cr}(\mathrm{VI})$ in GF AAS encouraged the investigation of different approach for total $\mathrm{Cr}$ determination in 
saliva where $\mathrm{Cr}(\mathrm{III})$ and $\mathrm{Cr}(\mathrm{VI})$ coexists. The results indicated that the $\mathrm{Cr}(\mathrm{VI})$ is released from the orthodontic brackets of low quality. Considering the duration of the orthodontic treatment (2 years), the possibility of corrosion of the brackets in the oral environment deserves attention to avoid ingestion of highly toxic specie of chromium.

\section{ACKNOWLEDGMENTS}

We are grateful to Fundação de Amparo à Pesquisa do Estado de São Paulo (FAPESP) and Conselho Nacional de Desenvolvimento Científico e Tecnológico (CNPq) for financial support. P.V. Oliveira thanks CNPq by the grant (304961/2013-2).

\section{REFERENCES}

1. Sfondrini, M. F.; Cacciafesta, V.; Maffia, E.; Massironi. S.; Scribante, A.; Alberti, G.; Biesuz, R.; Klersy, C.; The Angle Orthodontist 2009, 79, 361 .

2. Luft, S.; Keilig, L.; Jager, A.; Bourauel, C.; Orthodontics \& Craniofacial Research 2009, 12, 43.

3. Haddad, A. C. S. S.; Tortamano, A.; Souza, A. L.; Oliveira, P. V.; Braz. Oral Res. 2009, 23, 399.

4. Mikulewicz, M.; Chojnacka, K.; Wo niak, B.; Downarowicz, P.; Biol. Trace Elem. Res. 2012, 146, 272.

5. Pazzini, C. A.; Marques, L. S.; Jorge, M. L. R.; Júnior, G. O.; Pereira, L. J.; Paiva, S. M.; The Angle Orthodontist 2012, 82, 653.

6. Bumgardner, J. D.; Lucas, L. C.; J. Dental Res. 1995, 74, 1521.

7. Badiei, H. R.; Enaney, J. M.; Karanassios, V.; Spectrochim. Acta, B 2012, 78, 42 .

8. Chatterjee, S.; Sarkar, S.; Bhattacharya, S.; Chem. Res. Toxicol. 2014, 27, 1887.
9. Singh, J.; Carlisle, D. L.; Pritchard, D. E.; Patierno, S. R.; Oncol. Rep. 1998, 5, 1307.

10. Tsalev, D. L.; NATO Science for Peace and Security Series C - Environmental Security, 2010.

11. Gomez, V.; Callao, M. P.; Trend. Anal. Chem. 2006, 25, 1006.

12. Bermejo-Barrera, P.; Barciela-Alonso, M. C.; Pérez-Fernandez, B.; Bermejo-Barrera, A.; Spectrochim. Acta, B 2003, 58, 167.

13. Rao, T. P.; Karthikeyan, S.; Vijayalekshmy, B.; Iyer, C. S. P.; Anal. Chim. Acta 1998, 369, 69.

14. Chwastowska, J.; Skwara,W.; Sterliniska, E.; Pszonicki, L.; Talanta 2005, 66, 1345.

15. Martendal, E.; Maltez, H. F.; Carasek, E.; J. Hazard. Mater. 2009, 161, 450 .

16. Ozmen, M.; Can, K.; Akin, I.; Arslan, G.; Tor, A.; Cengeloglu, Y.; Ersoz, M.; J. Hazard. Mater. 2009, 171, 594.

17. Kim, M.; Stripeikis, J.; Tubino, M.; Spectrochim. Acta, B 2009, 64, 500.

18. Huang, Y. F.; Li Y.; Jiang, Y.; Yan, X. P.; J. Anal. At. Spectrom. 2010, 25 , 1467.

19. Machackova, L.; Zemberyova, M.; Inter. J. Environ. Anal. Chem. 2009, 89,705 .

20. Luz, M. S.; Oliveira, P. V.; Braz. J. Anal. Chem. 2011, 4, 194.

21. Tarley, C. R. T.; Lima, G. F.; Nascimento, D. R.; Assis, A. R. S.; Ribeiro, E. S.; Diniz, K. M.; Bezerra, M. A.; Segatelli, M. G.; Talanta 2010, 100, 71.

22. Guerra, D. J. L.; Mello, I.; Resende, R.; Silva, R. A. S.; React. Kinet., Mech. Catal. 2013, 108, 317.

23. Leung, V. W. H.; Darvell, B. W.; J. Chem. Soc. Faraday Trans. 1991, 87, 1759.

24. Sturgeon, R. E.; Chakrabarti, C. L.; Langford, C. H.; Anal. Chem. 1976, 48,1792 .

25. Wendl, W.; Müllervogt, G.; Spectrochim. Acta, B 1984, 39, 237. 